\title{
Migration Networks and the Moroccan Tourism: A Panel Data Analysis
}

\author{
DJELTI, SAMIR \\ Faculty of Economics, Business and Management Sciences, MCLDL Laboratory \\ University of Mascara (Algeria) \\ Correo electrónico: samirecodjelti@yahoo.fr \\ Hadj AHMED, MoHAmed \\ Faculty of Economics, Business and Management Sciences, MCLDL Laboratory \\ University of Mascara (Algeria) \\ Correo electrónico: mohamedhadjahmed29@gmail.com \\ GuELLIL, MOHAMED SEGHIR \\ Faculty of Economics, Business and Management Sciences, MCLDL Laboratory \\ University of Mascara (Algeria) \\ Correo electrónico: guellil.poldeva@gmail.com
}

\begin{abstract}
This contribution aims to study the migration and tourism nexus. In the developed countries, the effect of migration on tourism has been widely analyzed. For the developing countries, this topic is more interesting because of the role that diaspora plays in fostering tourism to the home countries. Based on the theoretical and empirical literature, the effect of migration networks on tourism will be tested. On the one hand, global migration networks can have a positive effect on tourism through the increase of borders permeability in the osmosis theory logic. On the other hand, at the micro level, migrant generations, transactions, preferences, and emigrants' life style can adapt, promote, and advertise tourism of the home countries. To estimate the global effect of networks on Moroccan inflows of tourists from the eight OECD principal immigration countries, the gravity model has been used. The analysed data considers the statistics of the nine countries during nine periods. The results show a significant correlation between Moroccan tourism inward tourism and emigration, in addition to the exogenous variables, either in the Fixed Effects Model or in Dynamic panel one using GMM method. The results indicate also a concordance of the two models results, the fact that strengthen their role as robust tools for exploring the migration and tourism nexus. The statistical results confirm the positive effects of migration networks on the Moroccan tourism.
\end{abstract}

Keywords: migration, networks, tourism, Morocco.

JEL classification: F22; L84.

MSC2010: 62J99; 62F10; 90B30. 


\title{
Redes de migración y turismo marroquí: un análisis de datos de panel
}

\begin{abstract}
RESUMEN
Esta contribución tiene como objetivo estudiar el nexo entre migración y turismo. En los países desarrollados, el efecto de la migración en el turismo ha sido ampliamente analizado. Para los países en desarrollo, este tema es más interesante debido al papel que juega la diáspora en el fomento del turismo a los países de origen. Con base en la literatura sobre migración y comercio, se probará el efecto de las redes de migración en el turismo. Por un lado, las redes mundiales de migración podrían tener un efecto positivo en el turismo a través del aumento de la permeabilidad de las fronteras en la lógica de la teoría de la ósmosis. Por otro lado, a nivel micro, las generaciones de migrantes, las transacciones, las preferencias y el estilo de vida de los emigrantes podrían adaptar, promover y publicitar el turismo de los países de origen. Para estimar el efecto global de las redes en las entradas de turistas marroquíes de los ocho principales países de inmigración de la OCDE, se ha utilizado el modelo de gravedad. Los datos analizados consideran las estadísticas de nueve países durante nueve períodos. Los resultados muestran una correlación significativa entre turismo marroquí y emigración, además de las variables exógenas, ya sea en el Modelo de efectos fijos o en el panel dinámico uno utilizando el método GMM. Los resultados indican concordancia de los resultados de los dos modelos, el hecho de que fortalecen su papel como herramientas robustas para explorar el nexo entre migración y turismo.
\end{abstract}

Palabras clave: migración, redes, turismo, Marruecos.

Clasificación JEL: F22; L84.

MSC2010: 62J99; 62F10; 90B30.

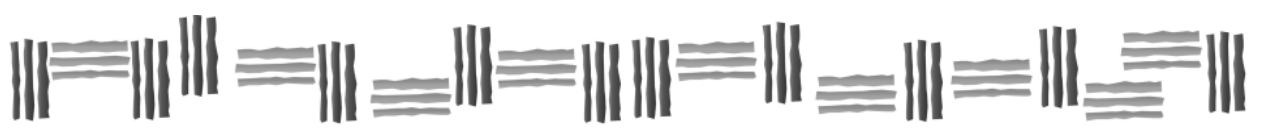




\section{Introduction.}

According to UN News, the number of international migrants world wild has, recently reached 272 million in 2019. In a more and more connected world, all the countries are concerned by this phenomenon; even the most isolated countries are, inevitably, emigration, immigration, and/or transit countries. In the same sense, the annual report of the World Tourism Organization (UNWTO, 2019) mentions that 1.4 billion people has travelled for tourism purposes in 2018. Even if tourists are not considered as migrants, in the international data, they represent a form of human mobility. Tourism is "a social, cultural and economic phenomenon, which imply the mobility of persons to countries or places abroad of their usual environment for personal, professional or business purposes" (UNDESA, 2010 , p. 1). If we consider that migration is globally, the mobility of persons from a place to another (Djelti, 2017a), then a migrant can be a tourist and vice-versa. Both involving the movement of people, migration and tourism are two types of mobility, but there has been very little research into their relationship (UNWTO, 2009).

The majority of the existing theories of international migration belong to a special discipline, focuses on a special type of migration with a special definition, in a limited space, and during a precise period. Recently, the unifying theory of human migration, called osmosis, presented an attempt to explain the whole phenomenon of human migration. According to this theory, migration includes all the movements of humans from a place to another. Because of the exclusion of the notion of time, this theory represents the first logic that explains tourism as a migration flow.

In general, the majority of the empirical studies have concluded a positive effect regarding migration and tourism nexus. More precisely, the effect of migration on tourism goes in the two opposite directions. The first one is when the migrant invites his friends and relatives to visit (VFR) his host country. The studies of this relation have shown the positive effects of immigration on the host country, through the net increase of tourism flows.

The second direction represents tourism from the host to the home country. Even if the mechanisms of such relation are not clear, the majority of studies have confirmed the positive correlation between migration and tourism in the home country. The results of such studies encourage the home countries to improve their tourism sectors. In the same sense, on the one hand, tourism investment does not require large amounts of capitals, high skilled labor or high technology. On the second hand, it creates, directly and indirectly, the rise of the economic activity in the visited places (and elsewhere), essentially because of the demand of goods and services produced and provided (UNWTO, 2014). Such characteristics make tourism investment affordable and important for both the developed and the developing countries. Therefore, the tourism sector represents a relevant opportunity for boosting the development of the developing countries, especially those with important tourism potential.

In fact, the French ministry of tourism has declared that this sector returns represented $7.4 \%$ of the GDP, 350000 company and two million jobs (Faure, 2017). In the other side of the Mediterranean Sea, tourism seems to be more important for the Moroccan economy. Ranked $62^{\text {nd }}$, the Moroccan tourism represented $11 \%$ of the GDP and created 548000 direct jobs (5\%) in 2018. In the same sense, tourism returns represented 73.2 million Dirhams, the equivalent of $18 \%$ of the goods and services exportations in 2018 (Moroccan Tourism Ministry, 2020).

In fact, despite the annual changes in the tourism countries ranking, France, USA and Spain are almost, always presented in the top ten. However, China and Turkey have climbed from the bottom to the top ten (UNWTO, 2014). "France, the United States, Spain and China continued to top the rankings in both international arrivals and receipts. In receipts, Thailand climbed three places to the $6^{\text {th }}$ position, and Hong Kong (China) climbed one place to the $9^{\text {th }}$. Mexico moved up one position to come 9 th in arrivals" (UNWTO, 2016). 
Regarding migration and tourism, according to Scalabrin and Fitzgerald (2016), France is the main destination of the Moroccan migrants. Furthermore, a new survey revealed that from about the $10.31 \%$ of the French that travel to Africa, $30.43 \%$ choose Morocco as the main destination (Faure, 2017). Is there a global framework that explains this relationship? What are its real channels and mechanisms? And what about its evidence in Morocco?

In this article, the theoretical backgrounds of both international migration and tourism will be presented, and the channels connecting them will be defined. More precisely, the second direction of the effect of migration on tourism will be theoretically analyzed at the global and the micro level. At the global level, it represents the effect of diaspora on inward tourism of the home country. At the micro level, an attempt to define the effects of the networks of migrants and their descendants on enhancing tourism will be presented. Finally, in order to check such theoretical predictions, the link between Moroccan migration and tourism from the main destination countries will be estimated.

\section{Literature Review.}

The existing theories of international migration does not consider tourism as a type of migration flows. They try to explain special cases of migration in a special space and during a limited time. In the same sense, migration studies focus on labor migration, forced migration, climate migration, female migration, etc. This reality makes impossible the study of tourism flows as a form of migration. In economics, migration and tourism are two different topics that could be crossed through the study of their causality.

The study of migration effects on tourism in the home countries includes a combined literature. Put it another way, the two theoretical frameworks have to be presented. First, the standard literature on immigration and tourism flows to the host countries through the Visiting Friends and Relatives (VFR) represent the origin of this topic. Second, the literature on emigration and development through the migration networks has to be presented and discussed.

\subsection{Visiting Friends and Relatives (VFR).}

For the economists who have developed the VFR literature, the principal variable is tourism and the aim of their studies is to explain tourism determinants, rather than understand migration and tourism nexus. Traditionally, tourists ranking is based on the purpose of their trip (leisure, business, VFR...). The concept of VFR was used for the first time by Jackson's (1990), who observed the continued growth of this type of tourism. Dwyer and Forsyth (1993) have predicted that migration and tourism are interconnected and their causality goes in the both directions. Their analysis supposes a positive correlation between immigration and tourism inflows in the host countries. Williams and Hall (2002) has confirmed the first analysis, and their conclusions go hand in hand with the effect of immigration on the demand of tourism through the Visiting Friends and Relatives (VFR).

Later, researchers have used a dynamic panel data to explore the nature of the connection between immigration and tourism demand in Portugal during the period 1995-2008 (Leitão \& Shahbaz, 2012). The research results have revealed a significant increase in the Portuguese tourism during the periods of important immigration from the developing countries. More precisely, the study has concluded that income, immigration shocks, population, and distance between Portugal and the origin countries are the main tourism determinants.

In their study of tourism and migration, Dwyer et al. (2014) have divided tourism into two flows: outward and inward. Furthermore, they have considered three types for each flow: the total, the VFR, and the non-VFR. Empirically, they have estimated the correlation of these three variables with migration flows in 1991 and 2006. The study has concluded a strong and important correlation between migration and VFR as well as non-VFR. 
Etzo, Massidda and Piras (2014) have focused on immigration and tourism in the Italian case. Their study was based on an Italian dynamic data on bilateral tourism from 65 countries between 2005 and 2011. More precisely, they have used the arrivals, the spending of tourists, and the number of nights spent. For more precision, they have considered the aggregate and desegregate flows of vacancies and work. The study findings revealed a very strong correlation between migration and tourism. According to them, such correlation exceeds, even the VFR effect.

Massidda and Piras (2015) have investigated the effect of interregional migration on Italian domestic tourism demand. The authors have proposed a dynamic panel data and used three panel estimators characterized by different homogeneity assumptions imposed on the parameters. Before the panel regressions, they have performed standard co-integration analysis. Their analysis revealed a strong positive correlation between per-capita domestic tourism nights and per-capita internal migration stock (Massidda \& Piras, 2015). According to the authors, "this evidence extends the migration-tourism nexus, already established at the international level, to the intra-national scale and reinforces the idea that host regions should not overlook the role of migration when designing their tourism policies" (Massidda \& Piras, 2015, p. 585).

Santeramo and Morelli (2016) have recons that the gravity models have been widely used to study tourism flows. They have focused their analysis on the agritourism in Italy. According to them, the peculiarities of the segmented international demand for agritourism in Italy are examined by means of a novel approach: a panel data quantile regression. By collecting data for 33 home countries between 1998 and 2010, the authors have characterized the international demand for Italian agritourism with a large data set. The study has revealed that distance and income are the major determinants.

In general, by using different methods and studying different countries, the majority of studies concluded the same VFR positive correlation. Therefore, the theoretical predictions about the correlation between immigration and inward tourism in the host countries have been empirically confirmed.

\subsection{Migration Networks and Tourism to the Home Countries.}

Unlike the first literature on VFR, the second one belongs to economic migration studies. These economists think that migration could affect positively trade, FDI, technology etc., and therefore the whole economy of the home countries. According to this literature, such effects are channelized by migration networks. Greif (1989, 1993), Weidenbaum and Hughes (1996), Gould (1994), Rauch and Casella (1998), and Combes et al. (2003) have demonstrated that migration networks have a positive effect on trade.

The theoretical explanation of the relationships between migration networks and trade is based on the information about the market, the language, the preferences, and the personal contracts (Gould, 1994). According to Gould (1994), such information could foster trade between the host and the home countries through two effects: First, the transaction effect, in which migrants represent a channel of information that decrease directly the costs of trade. The second is the preference effect, which is explained by the information about the preferences of the home population. In general, migrants are not only a source of information about the preferences of the home population, but a mean for the decrease of trade costs. The majority of studies have used the gravity model to detect the positive global effect of migration networks on trade. Djelti (2016) has concluded that, despite the positive effect of migration networks on exportation, a $10 \%$ rise of emigration creates a commercial deficit of $0.22 \%$ in Algeria.

\subsubsection{The empirical studies}

Based on a data of bilateral tourism from 34 OECD countries to 52 middle-to low-income countries between 1995 and 2010, Balli et al. (2016) have tried to determine and compare the effects of immigration, trade, and institutional quality on tourism in the immigrants' home countries. The results have confirmed the positive effects of OECD immigrants on advertising tourism of their home 
countries. According to the authors, these results concern all the countries of the sample except of the African ones. The study has also shown that the quality of institutions, freedom, and civil liberty represent relevant indices of tourism destinations selection. According to the authors, a massive $8 \%$ of the variation in tourism flows can be accounted for these factors (Balli et al., 2016). The study results concern, also the whole sample except of the European and African destinations. The authors think that: "this feature of the data exists because European (African) countries are so similar to each other, and small differences in the indexes do not matter at the top (bottom) of the distribution" (Balli et al., 2016).

Recently, Takahashi (2019) have demonstrated the nexus of tourism demand and the migrants from Small Island Developing States (SIDS) in the Pacific region. According to the author, emigrants are an important element of island society and the tourism industry is crucial for these islands. Based on this reality, the author has explored a tourism demand model, which considers the regional differences of ten island states. The econometric analysis concludes that migrants generate tourism demand. Takahashi (2019) recommends that migrants should be considered as one of the important possibilities for generating tourism demand.

According to Taing (2019), Morocco was the first African country to abolish visas for Chinese nationals in 2016. Since then, the number of tourists has increased steadily, and flows have taken diverse forms, while their dynamics are less known. The author explores the opposite relationship between migration and tourism and focuses on the evolution of Chinese migration to Morocco since the abolition of tourist visas for Chinese citizens. In addition, it highlights Chinese movement towards the South of the Mediterranean in the context of the new silk roads. Taing (2019) thinks that, such new roads are shaping the new map of the Chinese diaspora.

Djelti et al., (2020) suppose, theoretically, that migration networks foster tourism to the origin countries. According to them, the effect is composed of migrant generations, transactions, preferences and emigrants' life style effects. The authors think that these effects can adapt, promote and advertise tourism to the countries of origin. They estimate a gravity model of effect of networks on Moroccan tourism inflows from the eight principal immigration countries during the periods $(2000,2010,2011$, 2012, 2013 and 2014). The results show that a $10 \%$ increase in Moroccan migration rises the real value of tourism inflows by $1.3 \%$.

More recently, based on an intra-European data (2000-2015), and by using complex-network analysis and gravity models, Provenzano (2020) has built two country-to-country networks to map the effect for each studied year. In addition, Provenzano (2020) has revealed the connections between states shaped by migration stocks and tourism flows. By using several econometric analyses, he has investigated the main determinants of the correlation patterns between the two networks. This new study has concluded a quite similar topological structure for the tourism and migration networks as well as to a significant and reciprocal direct influence between tourism and migration movements inside the European Union (Provenzano, 2020). In the same sense, this study has not detected a relevant indirect causal relationship between tourism and migration nexus.

In general, the new and the ancient findings of the empirical studies have confirmed the positive effect of migration on tourism in the two directions. Regarding migration and tourism to the home countries, the effect is present but there are other factors that could strengthen of weaken this effect. In addition, the majority of studies need a strong theoretical forecast.

\section{Toward a Theoretical Essay.}

In this article, the theoretical explanation, between migration and tourism, both on the global and the micro level, will be explored. This part will exclude the VFR effect and focus, only on the second direction of migration and tourism. More precisely, when we talk about migration and tourism in the following parts of this article, we mean emigration and tourism to the home countries. 


\subsection{Migration, Networks and Tourism: A Global View Framework.}

Recently, the osmosis theory of human migration (Djelti, 2017b) defined migration as the mobility of humans from one place to another. Such large definition encompasses tourism and considers it as a form of migration. The osmosis theory explains the force of migration by the difference of migration pressure, which is determined by the natural determinants of human migration (water availability, climate, security and, population density) (Djelti, 2017a). Put it simply, migration occurs from the country with low migration pressure to the country with high migration pressure. This same theory explains the direction of migration by the degree of borders permeability. More precisely, migrants tend to cross the most permeable borders in the direction of the highest migration pressure countries.

In addition, this theory introduces migration networks and control policies as two opposite forces, which determine the degree of borders permeability (Djelti, 2018a). In other words, the more migration networks are strong, the more borders are permeable and vice versa for control polices. Networks represent "sets of interpersonal ties that connect migrants, former migrants, and non-migrants in origin and destination areas through ties of kinship, friendship, and shared community origin" (Massey \& Denton, 1988, p. 396). The osmosis theory argue that networks guarantee a considerable degree of permeability. Ancient colonialism, for instance, makes the networks stronger and the permeability higher.

In the osmosis analogy, the water continues to move in the two directions until the equilibrium. This what explains tourism flows in the osmosis logic. Tourism is not guided only by migration pressure in the host countries, but it is a permanent movement in the two directions. Therefore, networks represent a relevant determinant of permeability and consequently they boost tourism. However, what about the micro level? How could networks foster tourism?

\subsection{A Zoom on the Micro Level of Networks and Tourism.}

In this section, the analysis will be focused on migration networks and tourism channels at the micro level, to understand the possible effects. In fact, the interconnection between migration and tourism creates confusions between their measures. Migrations' data consider migrants as non-resident in the home country and their visit as tourism. This represents a source of two confusions. The first one is related to the separation of generations. The second one concerns their money. In this contribution, the first generation is considered as migrants and the money they spend as remittances. The second and the next generations, in addition to their new networks (in-laws, friends, colleagues...) are considered as tourists. Therefore, the money they spend in the home country are considered as returns of tourism. Based on the theoretical framework about migration and trade, migration generations are more likely to foster tourism then the migrants themselves because they are more integrated in the host country. The following effects of networks on trade, presented in Figure 1 could be adapted on tourism.

First, according to Gould (1994), the transaction effect is represented by the channel of information that migrants generate. Such information could, directly, decrease the cost of trade. The information could also be on the tourism nature, quality, and price in their home country, including the touristic historical places, cultural activities, traditional products, tourism infrastructures etc. Furthermore, information about the quality of services and the corresponding prices could reduce both, the monetary and the psychological costs of tourism. To sum up, if we replace trade with tourism, the migrants could serve as a channel of information in the host country that promote tourism of their home country.

Second, regarding trade, the preference effect represents the information about the preferences of the home population, that migrants provide for the exporters of the host country. If we consider tourism, this effect will be inversed; migrants provide information to their home countries about the host country tourists' preferences. In the same sense, because of the migrant and their generations' integration in the host society, migrants' behavior could reflect the tourists' preferences. Such information is of great relevance for adapting tourism services by considering the tourists' preferences. 
Finally, the immigrants' way of life in the host country, their customs, traditions, local products, meals... could contribute to the advertisement the home country tourism.

Figure 1. The Effects of Migration on Tourism.

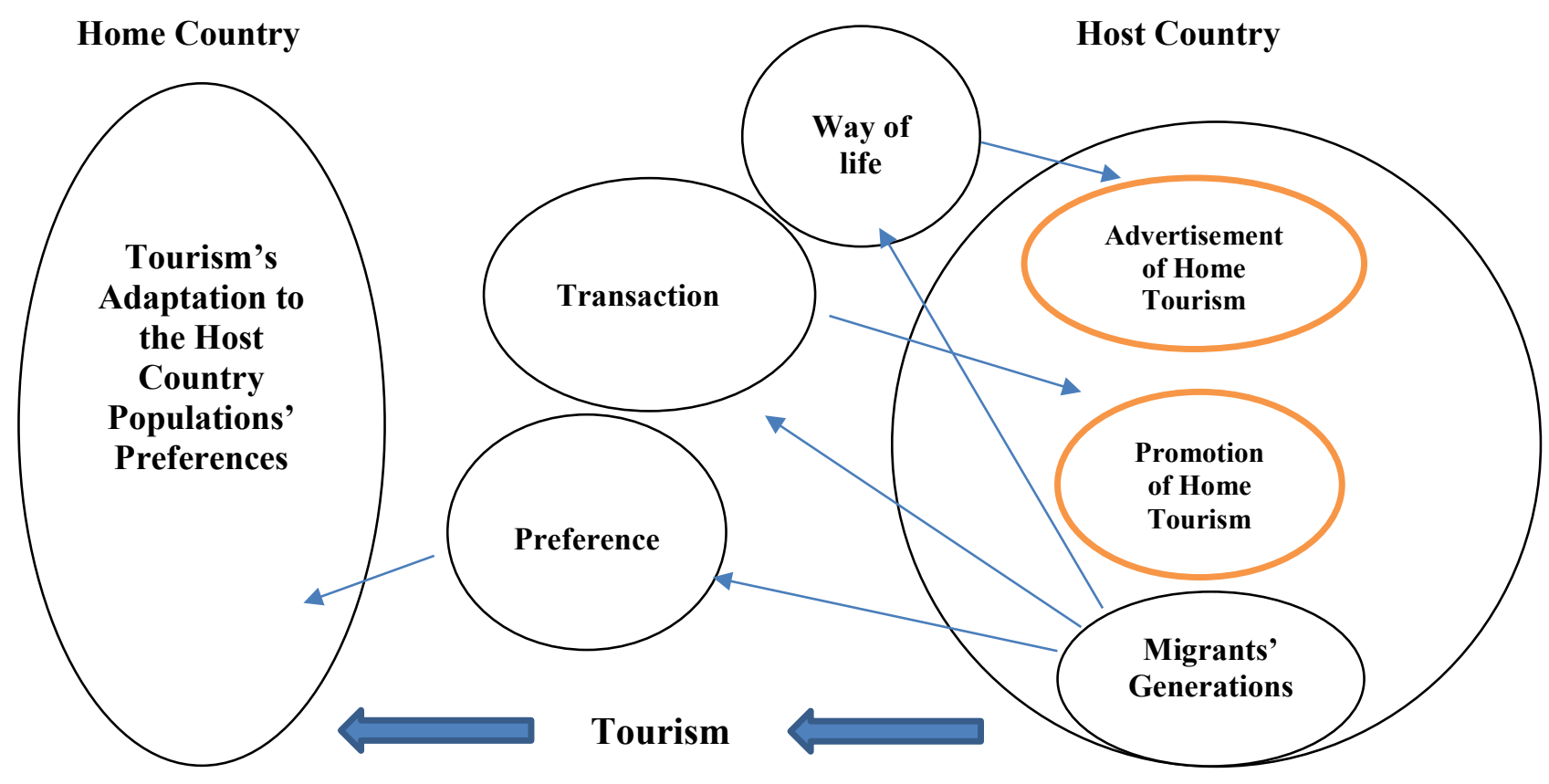

Source: Own elaboration.

The micro framework predicts that migration networks could affect positively tourism through migrants' way of life, that advertise it, the transaction effect that promote it, and the preference effect that help to adapt it to tourists' preferences. Therefore, migration does not only affect positively tourism to the host countries, it could improve it.

\section{The Model Estimation.}

On the one hand, Morocco's migration networks represent one of the most important in terms of size and diversity in the Mediterranean region. On the other hand, it is ranked as one of the most attractive African tourism destinations. In order to check the global theoretical predictions, the effect of Moroccan migration on tourism will be globally estimated. Based on the gravity model, the global determinants of tourism, including international migration, in addition to determinants related to migration networks will be estimated. In the empirical studies, the standard version of the gravity model, with tourism as the dependent variable, is given by the following equation:

$$
\text { TOURhm }=\mu \frac{G D P h G D P m}{D h m}
$$

TOURhm: Tourism flows from the host countries $(h)$ to Morocco $(m)$.

$\mu$ : Constant.

GDPh: GDP of the host countries.

GDPm: GDP of the home country (Morocco).

Dhm: Distance between the host country $h$ and the home country $m$. 
As it is represented in the precedent equation, our dependent variable is the flows of tourism from the main host countries of Moroccan emigrants to Morocco (TOURhm). The standard variables of the Gravity equation have been saved. In the same way, migration flows from Morocco to the host countries (EMIGhm) and population (POPh) have been introduced as determinant variables. Furthermore, two dummy variables, namely: colonialism relations (COL) and common language (Lang) has been used as control variables.

$$
\begin{aligned}
\ln (\text { TOURhm })= & \ln (\mu)+\ln (G D P h)+\ln (G D P m)+\ln (E M I G m h)-\ln (D m h)+\ln (P O P h) \\
& +C O L+\operatorname{lANG}+\delta
\end{aligned}
$$

POPh: Population size.

COL: Ancient colonial ties.

LANG: The common second official langue (because of the absence of a common mother language).

The collected data considers bilateral statistics of Morocco with eight OECD developed countries during nine periods $(2000,2010,2011,2012,2013,2014,2015,2016$, and 2017). Bilateral migration statistics are available at OECD immigration data (https://stats.oecd.org/Index.aspx?datasetcode=MIG\&Lang=fr), GDP (PPP constant 2011, international US Dollars) and population at the World Bank data (https://databank.worldbank.org/reports.aspx? source=2\&series=NY.GDP.MKTP.PP.KD\#). The rest of statistics are available in the official website of CEPII regrouped in "Gravity Data" (http://www.cepii.fr/cepii/en/bdd_modele/presentation.asp?id=8).

\subsection{The Unit Root Tests and Correlations.}

The estimation was started by the unit root tests on panel data (LLC, IPS, BRT, and MW), the series stationarity analysis, in order to investigate the stationarity of the used series. The results of these tests are presented in the following tables.

Table 1 shows the results of the five stationarity tests. It is clear that all the series are stationary at the firs level difference. Such stationarity results, for all countries in the level, allow us to estimate the model. This means also, that all the variables are integrated of order 0 . Regarding the correlations between the tourism flows to Morocco and the explanatory variables of the model, they are presented in the following table.

\begin{tabular}{|c|c|c|c|c|c|}
\hline Methods & $\begin{array}{l}\text { Levin, Lin and } \\
\text { Chu (LLC) }\end{array}$ & $\begin{array}{c}\text { Breitung } \\
\text { t-stat }\end{array}$ & $\begin{array}{l}\text { Im, Pesaran } \\
\text { And Shin } \\
\text { (IPS) W-stat }\end{array}$ & $\begin{array}{c}\text { MW - ADF } \\
\text { Fisher } \\
\text { Chi-square }\end{array}$ & $\begin{array}{c}\text { MW - PP } \\
\text { Fisher } \\
\text { Chi-square }\end{array}$ \\
\hline \multicolumn{6}{|l|}{ Variables } \\
\hline Log TOURhm & $\begin{array}{l}-29.4303 \\
(0.0000) *\end{array}$ & $\begin{array}{l}0.35724 \\
(0.6395)\end{array}$ & $\begin{array}{l}-6.72604 \\
(0.0000)^{*}\end{array}$ & $\begin{array}{c}89.1743 \\
(0.0000) *\end{array}$ & $\begin{array}{c}116.499 \\
(0.0000)^{*}\end{array}$ \\
\hline Log EMIGmh & $\begin{array}{l}-3.05874 \\
(0.0011)^{*}\end{array}$ & $\begin{array}{l}2.84862 \\
(0.9978)\end{array}$ & $\begin{array}{r}-0.17000 \\
(0.4325)\end{array}$ & $\begin{array}{c}22.6153 \\
(0.0244) *\end{array}$ & $\begin{array}{c}51.4992 \\
(0.0000)^{*}\end{array}$ \\
\hline Log GDPm & $\begin{array}{l}-142.421 \\
(0.0000) *\end{array}$ & $\begin{array}{c}0.19553 \\
(0.5775)\end{array}$ & $\begin{array}{l}-44.2291 \\
(0.0000)^{*}\end{array}$ & $\begin{array}{c}147.365 \\
(0.0000)^{*}\end{array}$ & $\begin{array}{c}147.365 \\
(0.0000)^{*}\end{array}$ \\
\hline Log GDPh & $\begin{array}{l}-21.2270 \\
(0.0000)^{*}\end{array}$ & $\begin{array}{l}-4.11488 \\
(0.0000) *\end{array}$ & $\begin{array}{l}-4.99892 \\
(0.0000) *\end{array}$ & $\begin{array}{c}41.1182 \\
(0.0005)^{*}\end{array}$ & $\begin{array}{c}100.270 \\
(0.0000)^{*}\end{array}$ \\
\hline
\end{tabular}

Table 1. The Unit Root Tests. 


\begin{tabular}{|c|c|c|c|c|c|}
\hline Log Dmh & -18.1281 (0.0599) & $\begin{array}{r}0.27724 \\
(0.7395)\end{array}$ & $\begin{array}{l}-5.95591 \\
(0.0310)^{*}\end{array}$ & $\begin{array}{c}41.1182 \\
(0.0035)^{*}\end{array}$ & $\begin{array}{c}100.270 \\
(0.0000) *\end{array}$ \\
\hline Log POP & $\begin{array}{l}-111.055 \\
(0.0000) *\end{array}$ & $\begin{array}{c}0.89919 \\
(0.8157)\end{array}$ & $\begin{array}{l}-37.9347 \\
(0.0000) *\end{array}$ & $\begin{array}{c}44.4065 \\
(0.0002)^{*}\end{array}$ & $\begin{array}{c}120.250 \\
(0.0000) *\end{array}$ \\
\hline
\end{tabular}

Source: Own elaboration.

Table 2 shows that Moroccan tourism is positively correlated to migration at $43.39 \%$. In addition, the colony and the common language are strongly correlated to both, the dependent variable and to migration compared to the other variables. Regarding distance, it has a negative medium correlation with the dependent variable. To avoid collinearity problems, we eliminated these three variables, which are also strongly correlated to each other. In fact, colonialism and the common language was used to detect migration networks, in case of their elimination, migration will replace them.

Table 2. The Matrix of Correlations.

\begin{tabular}{|c|c|c|c|c|c|c|c|c|}
\hline & TOURHM & EMIGMH & GDPM & \multicolumn{1}{c|}{ GDPH } & POP & \multicolumn{1}{c|}{ DMH } & COL & LANG \\
\hline TOURHM & 1.000000 & 0.433996 & 0.316035 & -0.029421 & 0.040994 & -0.505832 & 0.821531 & 0.612890 \\
\hline EMIGMH & 0.433996 & 1.000000 & 0.000367 & -0.001295 & 0.078082 & -0.445896 & 0.639454 & 0.554184 \\
\hline GDPM & 0.316035 & 0.000367 & 1.000000 & 0.060363 & 0.027110 & $2.10 \mathrm{E}-17$ & 0.000000 & 0.000000 \\
\hline GDPH & -0.029421 & -0.001295 & 0.060363 & 1.000000 & 0.989405 & 0.609123 & -0.056366 & -0.445591 \\
\hline POP & 0.040994 & 0.078082 & 0.027110 & 0.989405 & 1.000000 & 0.503439 & 0.030982 & -0.392697 \\
\hline DMH & -0.505832 & -0.445896 & $2.10 \mathrm{E}-17$ & 0.609123 & 0.503439 & 1.000000 & -0.635424 & -0.576267 \\
\hline COL & 0.821531 & 0.639454 & 0.000000 & -0.056366 & 0.030982 & -0.635424 & 1.000000 & 0.745356 \\
\hline LANG & 0.612890 & 0.554184 & 0.000000 & -0.445591 & -0.392697 & -0.576267 & 0.745356 & 1.000000 \\
\hline
\end{tabular}

Source: Own elaboration.

\subsection{Homogeneity Tests (Specification Tests of Hsiao).}

The choice of specification (homogeneity, heterogeneity) is very important to determine the structure of the panel. Hsiao (1986) proposes sequential tests to define the cases in which it is located. The three tests of Fisher from Hsiao's procedure have to determine if we have a model with specified individual time invariant. In this case, we can use panel data estimation. Hypothesis tests are constructed from statistics of Fisher (Wald test of restrictions on the coefficients). The results of these tests are presented in the following tables.

Table 3. Hsiao Test Results.

\begin{tabular}{|c|c|c|}
\hline Hypotheses & F-Stat & P-Value \\
\hline H1 & 90.23040 & $7.55 \mathrm{E}-24$ \\
\hline H2 & 1.318735 & 0.09215 \\
\hline H3 & 131.7054 & $5.60 \mathrm{E}-34$ \\
\hline \multicolumn{2}{|c|}{ Source: Own elaboration. } \\
\hline
\end{tabular}


We begin by testing the hypothesis: $\mathrm{H} 1$ = Null Hypothesis (panel is homogeneous) Vs $\mathrm{H} 2=$ Alternative Hypothesis. Therefore, we switch to the left branch of Hsiao's test graph and then, we test: H2 = Null Hypothesis: H3 Vs the Alternative Hypothesis: panel is heterogeneous. We accept the null hypothesis. Then, we move to the right branch of Hsiao's test graph, to test H3 = Null Hypothesis (panel is homogeneous) Vs Alternative Hypothesis (panel is partially homogeneous). We reject the null hypothesis and the panel has a structure of individual effects.

\subsection{Fixed or Random Effects? "Hausman Test".}

The specification test of Hausman (1978) is a general test that can be applied to many problems of specification in econometrics. Its most common application is the specification tests of individual effects in panel. It also serves to discriminate between fixed and random effects that we will study and test. The general idea of this test is both simple and general. As noted earlier, the Hausman test is a test that will allow us to determine whether, the coefficients of the two estimations (fixed and random) are statistically different. Under the null hypothesis $\mathrm{H} 0$ of orthogonality between the explanatory variables and the error term of the random effects model, both estimators -LSDV (Least Square Dummy Variable) and GLS (Generalized Least Squares)- are unbiased estimators. In this case, there should be no significant difference between the LSDV and GLS estimates of the various coefficients. The GLS method is then, retained, and the random effects is the appropriate model. However, the alternative hypothesis considers the fixed effect model as the appropriate one.

Table 4. Hausman Test.

\begin{tabular}{|l|c|c|c|}
\hline Test Summary & Chi-Sq. Statistic & Chi-Sq. d.f. & Prob. \\
\hline Cross-section random & 17.410610 & 4 & 0.0016 \\
\hline \multicolumn{3}{|c|}{ Source: Own elaboration. }
\end{tabular}

In the table above, the probability value is 0.0000 , which means statistically that we can reject the null hypothesis; therefore, the fixed effect model is more appropriate than the random one.

\subsection{Fixed Effects Model Estimation}

The results of the fixed effect model are presented in the following table.

Table 5. Fixed Effects Model Estimation.

\begin{tabular}{|c|r|r|r|r|}
\hline Variable & Coefficient & Std. Error & t-Statistic & Prob. \\
\hline C & -96.27968 & 19.54847 & -4.925177 & 0.0000 \\
\hline EMIGMH & 0.009464 & 0.070755 & 0.133761 & 0.8940 \\
\hline GDPM & 0.431496 & 0.228267 & 1.890314 & 0.0635 \\
\hline GDPH & 0.821204 & 0.750412 & 1.094338 & 0.2782 \\
\hline POP & 4.181663 & 1.420683 & 2.943416 & 0.0046 \\
\hline Fixed Effects (Cross) & & & & \\
\hline FR-C & 0.483523 & & & \\
\hline UK-C & -0.807722 & & & \\
\hline BEL-C & 7.359727 & & & \\
\hline GER-C & -2.565819 & & & \\
\hline ITA-C & -0.994513 & & & \\
\hline NETH-C & 4.938241 & & & \\
\hline USA-C & -9.858055 & & & \\
\hline SP-C & 1.444617 & & & \\
\hline
\end{tabular}




\begin{tabular}{|c|c|c|c|}
\hline & \multicolumn{2}{|c|}{ Effects Specification } & \\
\hline \multicolumn{4}{|c|}{ Cross-section fixed (dummy variables) } \\
\hline R-squared & 0.966103 & Mean dependent var & 12.67694 \\
\hline Adjusted R-squared & 0.959888 & S.D. dependent var & 0.785700 \\
\hline S.E. of regression & 0.157359 & Akaike info criterion & -0.709564 \\
\hline Sum squared resid & 1.485709 & Schwarz criterion & -0.330119 \\
\hline Log likelihood & 37.54429 & Hannan-Quinn criter. & -0.558506 \\
\hline F-statistic & 155.4605 & Durbin-Watson stat & 1.200767 \\
\hline Prob(F-statistic) & 0.000000 & & \\
\hline
\end{tabular}

According to the fixed effect appropriate model, the majority of the variables of the model are not separately but jointly significant at 0.000000 . In addition, the determination coefficient is equal to 0.966103 , which means that the exogenous variables explain $96.61 \%$ of the Moroccan tourism inflows from the studied eight developed countries. The given variables are expressed in natural logarithms; the coefficients can be interpreted as elasticity. Overall, the results of this study show that there is a strong long-term relationship between tourism and the explanatory variables.

The results obtained for the fixed effects model suggest that a 1\% increase GDPM, GDPH and POP increase the Moroccan tourism inflows, respectively by $0.431496 \%, 0.821204 \%$, and $4.181663 \%$. Regarding our main variable, a $1 \%$ rise in Moroccan emigration to the host countries increases tourism by $0.009464 \%$. These results highlight the involvement of exogenous variables to the Moroccan tourism.

\subsection{Redundant Fixed Effects Tests.}

The next test is the redundant fixed effects, which is used to test the significance of the effects. The null hypothesis in this test is that the effects are redundant. To examine the significance of effects, first the unrestricted model, which includes all the effects estimated. Then, the redundant fixed effects likelihood ratio is performed. We estimate one restricted specification i.e. with cross section fixed effects only. The following table consists a set of tests: the significance of the cross-section effects.

Table 6. Redundant Fixed Effects Tests.

\begin{tabular}{|l|c|c|c|}
\hline Effects Test & Statistic & d.f. & Prob. \\
\hline Cross-section F & 131.705406 & $(7,60)$ & 0.0000 \\
\hline Cross-section Chi-square & 201.253208 & 7 & 0.0000 \\
\hline
\end{tabular}

The set consists of two tests ("Cross-section F" and "Cross-section Chi-square") that evaluate the joint significance of the cross-section effects using sums-of-squares (F-test) and the likelihood function (Chi-square test). The corresponding restricted specification is the one, in which there are only period effects. The two statistic values (131.70 and 201.25) and the associated p-values strongly reject the null hypothesis (the cross-section effects are redundant). In other words, all the results indicate that the effects are statistically significant.

\subsection{Residual Cross-Section Dependence Test.}

It is commonly assumed that disturbances in panel data models are cross-sectionally independent, especially when the cross-section dimension $(\mathrm{N})$ is large. However, there is considerable evidence that cross-sectional dependence is often present in panel regression settings. Ignoring cross-sectional 
dependence in the estimation, can have serious consequences, with unaccounted for residual dependence resulting in estimator efficiency loss and invalid test statistics. There are varieties of tests for cross-section dependence in the literature. In our study, we use the following tests:

- Breusch-Pagan (1980) LM.

- Pesaran (2004) scaled LM.

- Baltagi, Feng, and Kao (2012) bias-corrected scaled LM.

- Pesaran (2004) CD.

The results of Residual Cross-Section Dependence Test are presented in the table below.

Table 7. Residual Cross-Section Dependence Test.

\begin{tabular}{|l|c|c|c|}
\hline \multicolumn{1}{|c|}{ Test } & Statistic & d.f. & Prob. \\
\hline Breusch-Pagan LM & 84.70459 & 28 & 0.0000 \\
\hline Pesaran scaled LM & 7.577470 & & 0.0000 \\
\hline Bias-corrected scaled LM & 7.077470 & & 0.0000 \\
\hline Pesaran CD & 1.652921 & & 0.0983 \\
\hline
\end{tabular}

Source: Own elaboration.

The top of the table displays the test hypothesis and information about the number of crosssection and period observations in the panel. The bottom portion of the table contains the test results. The first line contains results for the Breusch-Pagan LM test. The result shows the test statistic value, test degree-of-freedom, and the associated p-value. In this case, the value of the test statistic (84.70) is well into the upper tail of a $\chi_{28}^{2}$, and we strongly reject the null of no correlation at conventional significance levels.

The next two lines present results for the two scaled Breusch-Pagan tests. Both, the Pesaran scaled Breusch-Pagan LM, and the Baltagi et al. bias-adjusted LM tests are asymptotically standard normal, and the test statistic results of 7.58 and 7.08 respectively, strongly reject the null hypothesis at conventional levels. Note that in this study, the bias correction has a relatively small effect on the scaled $\mathrm{LM}$ statistic as $\mathrm{N}$ and $\mathrm{T}$ are of similar magnitude.

Since T (period) is relatively small, we may instead wish to focus on the results for the asymptotically standard normal Pesaran CD test, which are presented in the final line of the table. While the p-value of the Pesaran CD test statistic is upper than $0.5 \%$, the Pesaran CD test still does not reject the null hypothesis at conventional significance levels. Therefore, we note no correlation of Residual Cross-Section.

\subsection{Panel GMM Estimation of a Dynamic Model.}

Having done all the previous tests and estimated the relationship between Tourism Flows to Morocco and the explanatory variables of the Fixed Effects Model, we estimate the previous relationship under the dynamic panel model using GMM (Generalized Method of Moments) method. The estimation results are presented in the following table. 
Table 8. Estimated Dynamic Model.

\begin{tabular}{|c|c|c|c|c|}
\hline Variable & Coefficient & Std. Error & t-Statistic & Prob. \\
\hline $\mathrm{C}$ & -96.29538 & 19.55063 & -4.925436 & 0.0000 \\
\hline EMIGMH & 0.009415 & 0.070755 & 0.133071 & 0.8946 \\
\hline GDPM & 0.431233 & 0.228306 & 1.888833 & 0.0638 \\
\hline GDPH & 0.822334 & 0.750397 & 1.095865 & 0.2775 \\
\hline POP & 4.181154 & 1.420378 & 2.943691 & 0.0046 \\
\hline & \multicolumn{2}{|c|}{ Effects Specification } & & \\
\hline \multicolumn{4}{|c|}{ Cross-section fixed (dummy variables) } & \\
\hline R-squared & 0.966103 & \multicolumn{2}{|c|}{ Mean dependent var } & 12.67694 \\
\hline Adjusted R-squared & 0.959888 & \multicolumn{2}{|c|}{ S.D. dependent var } & 0.785700 \\
\hline S.E. of regression & 0.157359 & \multicolumn{2}{|c|}{ Sum squared resid } & 1.485709 \\
\hline Durbin-Watson stat & 1.200738 & \multicolumn{2}{|c|}{ J-statistic } & $2.39 \mathrm{E}-06$ \\
\hline Instrument rank & 12 & & & \\
\hline
\end{tabular}

Source: Own elaboration.

As mentioned above, we used GMM technique for obtaining estimates of parameters of the Dynamic panel relationship between Tourism Flows to Morocco and the explanatory variables. The coefficients of the dynamic panel model in Cross-section Fixed Effects are positive for all the exogenous variables and they are statistically significant at the 5\% significance. The coefficients could be interpreted as elasticity because the variables are expressed in natural logarithms. Overall, the obtained results of panel GMM method are the same of the fixed effects model estimation results.

Table 9. Cross-section Fixed Effects.

\begin{tabular}{|c|c|}
\hline CROSS-ID & Effect \\
\hline FR & 0.483513 \\
\hline UK & -0.807881 \\
\hline BEL & 7.360656 \\
\hline GER & -2.566161 \\
\hline ITA & -0.994404 \\
\hline NETH & 4.938717 \\
\hline USA & -9.859467 \\
\hline SP & 1.445027 \\
\hline
\end{tabular}

Source: Own elaboration.

The results obtained for the dynamic panel model in Cross-section Fixed Effects suggest that a 1\% increase in GDPM, GDPH and POP increase the Moroccan tourism inflows, respectively by $0.431233 \%, 0.822334 \%$ and $4.181154 \%$. Regarding the main variable of the study, a $1 \%$ rise in Moroccan emigration to the host countries increases tourism by $0.009415 \%$. These last findings (GMM) and those of the OLS estimation goes hand in hand with our predictions presented in the global theoretical model. In addition, these results confirm the robustness of our model and the efficiency of our results.

From an economic point of view, the results have shown a significant and positive effect of migration on tourism. Even if this effect is limited, comparatively to the other variables, it confirms our theoretical predictions. These findings strengthen also the findings of the limited effect of migration on tourism of the home countries in Europe and Africa (Balli et al., 2016). 


\section{Conclusions.}

Tourism represents a relevant opportunity for the economics of the developing countries. These same countries represent the home of migrants that have boosted tourism to their host countries through the VFR framework. This article aims to explore the opposite correlation, the effect of migration on tourism to the home countries.

According to the theoretical and empirical literature, migration could affect, positively, tourism flows to the home countries. Such effect of migration on tourism passes precisely through the migration networks channel. At the global level, we have predicted that migration networks increase the permeability of the borders, the fact that allow to more movements in the two directions. This way, migration networks foster tourism for both the home and the host countries.

At the micro level, migration generations increase directly tourism to the home countries and strengthen migration networks in the host country. In addition, migration networks generate three additional effects. First, the transaction one provides information about the nature quality and the price of tourism services that reduce tourism costs and promote it. Second, the preferences effects provide information about the tourism preferences of the host population and, then, helps to adapt tourism services in the home country. The third effect represents the immigrants' way of life, which advertises tourism of the home country in the host county. In general, the theoretical literature predicts that, migration networks could increase tourism to the home countries, and could help to improves it.

From an empirical point of view, in this article, we have used the gravity model to check the existence of the global effect of migration networks on tourism flows to Morocco. The dependent variable of the model was the flows of tourism from the main eight OECD host countries of Moroccan migrants. To explain tourism, we have considered the standard variables of the Gravity equation and added Moroccan migration to the host countries and other variables to the gravity model. Regarding the data, we have collected bilateral statistics of Morocco with the eight countries during nine periods $(2000,2010,2011,2012,2013,2014,2015,2016$, and 2017).

We have proceeded to OLS and GMM estimations and the results have confirmed the effect of migration on tourism. In addition, such results concordance, confirms the robustness of our model and the efficiency of our results. The GMM estimation's result suggested that a ten percent rise in the emigration rate from Morocco to the eight studied developed countries increases the real value of Moroccan inflows of tourism by $0.009415 \%$.

From an economic point of view, the results have shown a significant and positive effect of migration on tourism. Even if this effect seems to be limited, it confirms our theoretical predictions. These findings strengthen also the findings of the limited effect of migration on tourism of the home countries in Europe and Africa (Balli et al., 2016). In addition, these findings allow the developing countries to investigate about this limited effect and explore the channel of adapting their tourism services to the host population preferences.

\section{References}

Balli, F., Balli, H.O., \& Louis, R.J. (2016). The impacts of immigrants and institutions on bilateral tourism flows. Tourism Management, 52, 221-229.

Casella, A., \& Rauch, J. E. (1998). Overcoming informational barriers to international resource allocation: prices and group ties (No. 1978). CEPR Discussion Papers.

Combes, P.P., Lafourcade, M., \& Mayer, T. (2003). Can business and social networks explain the border effect puzzle? Available at SSRN 385908. 
Djelti, S. (2016). Réseaux migratoires et balance commerciale: Évidence de l'Algérie. Revue Algérienne d'Economie et de Management, 7(2), 1-11.

Djelti, S. (2017a). The Evolution of the Determinants of Human Migration. Paper presented in the International conference on "Crossing Boundaries: Youth, Migration, and Development" Alakhawayn university in Ifran, Morocco- March 2-4, 2017.

Djelti, S. (2017b). Osmosis: the unifying theory of human migration. Revue Algérienne d'Economie et de Management, 8(2), 48-59.

Djelti, S. (2018a). Osmosis of forced migration: The Plasmolysis Theorem. Paper presented in the United Nation University-Globalization, Culture and mobility internal research workshop, UNUGCM, Barcelona, Spain, 5 and 6 July, 2018.

Djelti, S. (2018b). The Importance of Understanding, Projecting and Planning for Safe, Orderly and Regular Migration.

Djelti, S., Guellil, M. S., \& Ahmed, M.H. (2020). Migration, tourism, and the development of the home countries: Evidence from Morocco. Global Journal of Business, Economics and Management: Current Issues, 10(1), 44-57.

Dwyer, L., Seetaram, N., Forsyth, P., \& King, B. (2014). Is the migration-tourism relationship only about VFR? Annals of tourism research, 46, 130-143.

Dwyer, L., \& Forsyth, P. (1993). Assessing the benefits and costs of inbound tourism. Annals of Tourism Research, 20(4), 751-768.

Faure, P. (2017). Memento du tourisme-édition 2017. Prospective, des Études et de l'Évaluation Économiques (P3E) de la DGE, SCIDE.

Galor, O., \& Tsiddon, D. (1997). Technological progress, mobility, and economic growth. The American Economic Review, 87(3), 363-382.

Gould, D.M. (1991). Immigrant links to the home country: empirical implications for US and Canadian bilateral trade flows (No. 9102). Federal Reserve Bank of Dallas.

Gould, D.M. (1994). Immigrant links to the home country: empirical implications for US bilateral trade flows. The Review of Economics and Statistics, 76(2), 302-316.

Greif, A. (1989). Reputation and coalitions in medieval trade: evidence on the Maghribi traders. The journal of economic history, 49(4), 857-882.

Greif, A. (1993). Contract enforceability and economic institutions in early trade: The Maghribi traders' coalition. The American Economic Review, 83(3), 525-548.

Hausman, J.A. (1978). Specification tests in econometrics. Econometrica: Journal of the econometric society, 46(6), 1251-1271.

Hiller, S. (2014). The Export Promoting Effect of Emigration: Evidence from D enmark. Review of Development Economics, 18(4), 693-708.

Hsiao, C. (1986). Analysis of PanelData. Econometric Society Monograph No: 11, Cambridge University Press. 
Infantino, F. (2019). Morocco: One 'Third Country' but Three National Contexts. In: Schengen Visa Implementation and Transnational Policymaking. Palgrave Macmillan, Cham.

Konan, D.E. (2011). Limits to growth: Tourism and regional labor migration. Economic Modelling, 28(1-2), 473-481.

Massey, D.S., \& Denton, N.A. (1988). Suburbanization and segregation in US metropolitan areas. American journal of Sociology, 94(3), 592-626.

Massidda, C., Etzo, I., \& Piras, R. (2015). Migration and inbound tourism: an Italian perspective. Current Issues in Tourism, 18(12), 1152-1171.

Massidda, C, Piras, R (2015) Does internal migration affect Italian domestic tourism? A panel data analysis. Tourism Economics, 21(3), 581-600.

Nuno, C.L., \& Muhammad, S. (2011). Migration and Tourist Flows. MPRA Paper 34905, University Library of Munich, Germany, revised 12 Nov 2011.

Provenzano, D. (2020). The migration-tourism nexus in the EU28. Tourism Economics, 26(8), 13741393.

Ratha, D., Eigen-Zucchi, C., \& Plaza, S. (2016). Migration and remittances Factbook 2016. World Bank Publications.

Rauch, J.E., \& Trindade, V. (2002). Ethnic Chinese networks in international trade. Review of Economics and Statistics, 84(1), 116-130.

Santeramo, F.G., \& Morelli, M. (2016) Modelling tourism flows through gravity models: a quantile regression approach. Current Issues in Tourism 19(11), 1077-1083.

Spotorno, M. (2019). Gentrification and European Entrepreneurship in Marrakesh. In: Paradiso M. (eds) Mediterranean Mobilities. Springer, Cham.

Stark, O., \& Bloom, D.E. (1985). The new economics of labor migration. The American Economic Review, 75(2), 173-178.

Taing, J. (2019). Les nouvelles routes de la soie au prisme des migrations: les visages de la présence chinoise au Maroc. Confluences Méditerranée, 109(2), 77-90.

Takahashi, K. (2019). Tourism demand and migration nexus in Small Island Developing States (SIDS): applying the tourism demand model in the Pacific region. Island Studies Journal, 14(1), 163-174.

United Nations, Statistical Division. (2010). International recommendations for tourism statistics 2008 ( No. 83). United Nations Publications.

United Nations World Tourism Organization (UNWTO), Blomberg-Nygard, A., \& Anderson, C. K. (2016). United Nations World Tourism Organization study on online guest reviews and hotel classification systems: an integrated approach. Service Science, 8(2), 139-151.

Weidenbaum, M.L., \& Hughes, S. (1996). The bamboo network: How expatriate Chinese entrepreneurs are creating a new economic superpower in Asia. New York: Simon and Schuster. 
Williams, A.M., \& Hall, C.M. (2002). Tourism, migration, circulation and mobility. In Tourism and migration (pp. 1-52). Dordrecht: Springer. 